Human Transit 



\title{
Human Transit
}

How Clearer Thinking About Public Transit Can Enrich Our Communities and Our Lives

\author{
Illustrations by \\ Eric Orozco \\ Erin Walsh \\ Alfred Twu \\ Daniel Howard \\ David Jones
}


(C) 2012 Jarrett Walker

All rights reserved under International and Pan-American Copyright Conventions. No part of this book may be reproduced in any form or by any means without permission in writing from the publisher: Island Press, Suite 300, 1718 Connecticut Ave., NW, Washington, DC 20009

ISLAND PRESS is a trademark of the Center for Resource Economics.

Library of Congress Cataloging-in-Publication Data

Walker, Jarrett, 1962-

Human transit : how clearer thinking about public transit can enrich our communities and our lives / Jarrett Walker; Illustrations by Eric Orozco ... [et al.].

p. $\mathrm{cm}$.

Includes bibliographical references and index.

ISBN-13: 978-1-59726-971-1 (cloth : alk. paper)

ISBN-10: 1-59726-971-9 (cloth : alk. paper)

ISBN-13: 978-1-59726-972-8 (pbk. : alk. paper)

ISBN-10: 1-59726-972-7 (pbk. : alk. paper) 1. Local transit. 2. City planning.

3. Community development. I. Title.

HE4211.W27 2011

$388.4-\mathrm{dc} 23$

2011026554

Printed on recycled, acid-free paper

Manufactured in the United States of America

$\begin{array}{llllllllll}10 & 9 & 8 & 7 & 6 & 5 & 4 & 3 & 2 & 1\end{array}$

KEYWORDS: bus, Complete Streets, density, express service, light rail, local service, mapping, mobility, network branding, operating costs, peak commute period, peak-only service, rail, rapid service, subway, transit fare, transit planning, transit policy, transit station, transit stop, urban form 




\section{Contents}

Acknowledgments | ix

INTRODUCTION | 1

1 What Transit Is And DOes | 13

2 What Makes Transit Useful? Seven Demands and How Transit Serves Them | 23

3 Five Paths to Confusion | 39

4 LINES, LOOPS, AND LONGING | 47

5 Touching the City: Stops and Stations | 59

6 Peak or All Day? | 73

7 Frequency Is Freedom | 85

8 The Obstacle Course: Speed, Delay, and Reliability | 97 
viii | CONTENTS

9 Density Distractions | 109

10 Ridership or Coverage? The Challenge of Service Allocation | 117

11 Can fares Be Fair? | 135

12 Connections or Complexity? I 147

13 From Connections to Networks to Places | 163

14 Be on the Way! Transit Implications of Location Cholce | 181

15 On the Boulevard | 205

16 Take the Long View | 215

Epilogue: Geometry, Cholces, Freedom | 223

Notes | 229

Index | 237 


\section{ACKNOWLEDGMENTS}

When it comes to cities, conversation and collaboration are the essence of creativity. This book arises out of twenty years of practice as a consultant plus fifteen years as an advocate, so it reflects conversations with many hundreds of engaged and dedicated people. It would be impossible to list everyone whose insights and perspectives influenced this book.

Still, three people are responsible for my being in this field at all. In the 1970s, Bill Allen, then of Portland's transit agency TriMet, found the time and patience to talk with an enthusiastic and detail-obsessed teenager. Tom Matoff, as TriMet's head of planning in 1983, gave me my first planning job and proved by his example that transit can be a humanistic and even aesthetic pursuit. Bonnie Nelson of Nelson\Nygaard gave me the break that restarted my planning career in 1990.

My most recent boss, Neil Cagney, of the Australian consulting firm MRCagney, saw the book's potential and helped push the project along. I'm grateful to all of my colleagues at his firm.

While writing, I spent a crucial month at the Centre for the Public Awareness of Science at the Australian National University, where the faculty and doctoral candidates were generous with feedback and insights; thanks to the Centre's Dr. Will Grant for that opportunity. I'm also grateful for the friendship of Professors David Hensher and Corinne Mulley of the University of Sydney's Institute for Transport and Logistics Studies, and especially their "Thredbo" conference series. I've also found an intellectual home at the planning division of the greater Vancouver transit agency TransLink, which supports creative thought as well as any university. 
Friends and colleagues who read the entire first draft include Brian Mills, Dale Favier, Gordon Price, Jack Lattemann, Yonah Freemark, Aaron Renn, and Bill Bryant. All offered helpful comments. I'm also grateful for the feedback of Peter Timms, Peter Schmiedeskamp, Sandy Thomas, Todd Gilens, Anthony Perl, Anthony Mifsud, David Sucher, Duncan Watry, and Jeff Deby. Charlotte-based architect Eric Orozco of Neighboring Concepts PLLC is credited as an illustrator but was also a key source of advice.

For the editing phase, Karl Lindeson and Lindsay Pratt gave me the use of their country home in Berrima, Australia, where the landscape and wildlife were a constant inspiration.

Crucial transit agency perspectives came from Nathan Banks of Portland's TriMet, Conan Cheung of the Los Angeles County Metropolitan Transportation Authority, Doran Barnes of Foothill Transit (east of Los Angeles), and Paul Bignardi of the San Francisco Municipal Transportation Agency. Responsibility for the book's ideas and errors remains with me.

My professional blog, HumanTransit.org, has drawn an international group of regular commenters whose lively discussion has done much to clarify my thinking. I wish I could list the hundred or more people who have contributed substantially to this conversation in blog comments, through email, and in person at various events.

Finally, my editor, Heather Boyer of Island Press, was patient, creative, and resourceful in helping produce this book. I'm grateful to Island Press for seeing the book's potential and helping to create its final shape. 